\title{
Beyond Adorno: Post-Critical Teaching of Popular Music in the German Educational System and Its Theoretical and Practical Challenges
}

\author{
Christofer Jost
}

\author{
Albert Ludwigs Universität Freiburg \\ christofer.jost@zpkm.uni-freiburg.de
}

\begin{abstract}
Over three decades the works of Frankfurt School member Theodor W. Adorno played an important role in the didactic conceptualization of popular music in Germany. This resulted in a predominantly analytical, ethic-centred and, in the end, pejorative agenda. Educationalists who advocated an affirmative approach to popular music needed to formulate "new" objectives that would serve as a true alternative to the highly elaborated Adornian framework. Though affirmative approaches finally became prevalent, the didactic situation remained delicate, since the teaching of popular music was also subject to general debates on how school education shall be constituted. Subsequently, the subject "popular music" became more and more tied to overall educational goals, whereas the objective dimension was increasingly ignored. The paper aims to reconstruct the complex path from critical to post-critical didactic efforts, finally addressing current issues, especially the notion of popular music as cultural practice. The "paradigm shift" towards affirmation is demonstrated on the basis of both theoretical works and curricular sources.
\end{abstract}

KEYWORDS: popular music education, didactic discourse, popular music studies, curriculum research, cultural practice 


\section{Introduction}

The works of Frankfurt School member Theodor W. Adorno had a major impact on the teaching of popular music in Germany after the Second World War. Almost two generations of educationalists and music teachers were influenced by the overall critical view of the artefacts of popular culture. This led to a peculiar discrepancy between institutional efforts and social realities since the mainstream youth population was highly enthusiastic about the new stars of jazz, rock ' $n$ ' roll, beat music and so forth. The radical change of juvenile listening habits after 1950 turned into a severe didactic problem. The altered musical preferences could no longer be neglected; however, the adult cultures in Germany initially were far from embracing the new sounds from the United States and Great Britain.

As a first step, the paper discusses the multiple reasons for the longevity of the Adornian thinking within the sphere of school education. This opens a deeper understanding of the challenges that resulted from the recognition of popular music as a subject. Accordingly, the next step is to unfold the actual topic of this paper: the era of post-critical music education. From this point of view it can be shown that the fundamental criticism of the Frankfurt School implied - not least because of its dominant ethic orientation - a simplification of the teaching process. At the same time, it maintained a sensibility for the complex interplay of music and society, providing a variety of suitable courses of action. Educationalists who advocated an affirmative approach to popular music were forced to link their didactic concepts to "new" theories that would offer an equivalent replacement of the highly elaborated Adornian agenda.

The issue that is raised in this paper also covers the present situation. Accordingly, a discussion on what aspects may be elevated in the future with regard to popular music education is put at the end. This concerns in the main the possible integration of analytic approaches on the cultural determinants of popular music realities. The "paradigm shift" from critical to non-critical teaching is reconstructed with the aid of theoretical works as well as curricular sources.

\section{Adorno's long shadow. Music teaching as counter-education to the musical realities}

Until the 1950s, the relationship of music educationalists and teachers with popular music was determined by depreciation and ignorance. In most cases, this resulted from a conservative interpretation of cultural criticism. Following this, it appeared as the main task of music teaching to preserve the heritage of German and European high culture. It was left to Adorno and his fellow Frankfurt School scholars to challenge the common cultural criticism of the time, introducing new approaches to the analysis of contemporary culture. In this sense, and with regard to popular music, a gap was filled. Subsequently, educationalists explicitly referred to the "new" modes of reflection or at least acted in the spirit of them. Today, the diffusion of Adorno's works has certainly passed its peak. Various academic scholars have been concerned with Adorno's critique of popular music; quite a few of them provide a profound critique of his theory of mass culture (see 
Prokop 2003; Kohler and Müller-Doohm 2008). Consequently, only the key points shall be discussed here.

If it were possible to identify an essence within the immensity of the Adornian works, this undertaking would surely have to refer to the critique of capitalist ideology. According to this, mass culture appears as the outcome of a world order in which the aim of making profit pervades every sphere of life. A basic feature of capitalist societies is the culture industry, which is laid out to keep the citizens in a state of immaturity. Moreover, the culture industry bears the blame that the art experience gives way to the enjoyment of commodities. By this means, art is increasingly replaced by entertainment, which - on the other hand - has the effect that art turns into the (desirable) antithesis of the existing social realities (see Adorno 1983). Art is an end in itself and therefore independent of any economic context.

The disintegration of the "real" art experience could proceed because those being involved in the art making process took on the economic (meaning capitalist) logic of standardized production processes. The extensive dissemination of art-like artefacts evokes certain emotions on a constant basis, which, in the long term, affects the consumer's needs and musical preferences (Adorno 1990: 302). According to the (early) Frankfurt School agenda, this leads to a circle of manipulation and collective need - a circumstance that is regarded as symptomatic for the existing social realities (Horkheimer and Adorno 1998: 129). From the constant circulation between the poles of manipulation and need, the culture industry generates its peculiar technique of creating standardized stimuli. Product differentiation is then initiated by the culture industry itself (ibid.: 307-309). The recipient's impression of the ever varying is evoked due to the targeted use of specific compositional details and effects. Adorno emphasizes this aspect by using the example of jazz music. Hence, jazz as such is not composed, but is based on the interpretation of the already existing song material. It is therefore an essential part of jazz that the aesthetic principle of composition is replaced by the ability to confirm improvisation rites. The musical execution is virtually "sportified" by a system of effects and details (Adorno 1992: 132). Hereafter, the archetypal consumer of jazz (and other "commodities") is to be characterized by the atrophy of imagination and spontaneity (Horkheimer and Adorno 1998: 134-135). It is crucial to the Adornian approach that the reasons for such deficits are to be detected in the products themselves.

The first didactic frameworks that referred decidedly to the Adornian agenda were not long in coming. A particularly prominent example is Michael Alt's monograph Didaktik der Musik ("The Didactics of Music", Alt 1968). ${ }^{1}$ At the time, it marked a departure from the tradition of song-based music education, but was also challenged immediately after its publication by various music educationalists (the main criticism referred to the bourgeois understanding of art). It ties in both Adorno's cultural diagnosis - with its main thesis of passive recipients consuming standardized cultural products - as well as the advocacy of an orientation away from popular music towards the (desirable) antithesis of "art". Quite remarkable for the time - and quite to Adorno's taste - is the postulation to focus on the intertwining of music with all areas of society, however, always in association with the idea of disclosing the manipulative forces which are immanent in the popular music artefacts. In short, this means: music analysis as social criticism. 
Alt (1968: 37) considers the changes which took place in the field of music culture after World War II as a youth-related phenomenon. In his understanding, popular music could enter the intimate world of juvenile everyday life because it compensates for the social isolation that is caused by modern mass society. Hence, popular music must be regarded as an emotionell aufgeladenes Musikgut ("emotionally charged musical commodity"; ibid.: 38) which leads the consumers to believe that with its help they will come in contact with like-minded people. It is therefore a main educational objective to free the youngsters from the manipulative processes which they are exposed to due to the ubiquitous culture industry. Thus, the music lesson serves as a kind of musikpädagogische Lebenshilfe ("music pedagogic life coaching"; ibid.). Eventually, demystifying popular music-related behaviour patterns is propaedeutic, in the sense that it makes the world of art accessible to the students. The creative potentials of young people are to be unleashed for the purpose of an intensive examination of the musical artwork. ${ }^{2}$

Also linked to Adornian thinking is Hermann Rauhe's outline of a jazz didactics (Rauhe 1962). Whereas in other conceptions of the time popular music represents only one (mostly diminutive) element of a broader reflection on the objectives of music education (as in Alt's work above), here, a specific variety of popular music, to wit jazz, serves as the actual subject. In this sense, Rauhe's conception occupies a special status in the history of music education in Germany. ${ }^{3}$ But nevertheless, it cannot be rated as a breakthrough to an unbiased dealing with popular music.

Rauhe (1962: 6) sees the reasons for the juvenile jazz enthusiasm in the constitution of adolescent feelings. He certifies the youth a peculiar ambiguity and vagueness of feelings, a conscious tendency towards the blurred and vague. This tendency finds its musical counterpart in jazz music, especially in the disguise of the triads (here, the reference to Adorno's dialectic aesthetics appears in its most distinct form). Another reason for the "youth phenomenon" jazz can be found in its protest function. According to Rauhe, young people use jazz as a medium of detachment from the well-organized world of adult everyday life. It turns out that the socio-psychological approach prepares the legitimacy of a curricular treatment of jazz. ${ }^{4}$ The intensive study of jazz music in class shall show students that their needs are taken seriously by the teacher. Eventually, this form of recognition follows the intention to undermine the protest function of jazz and to soften the passionate feelings about the music. Moreover, the students' enthusiasm is to be transferred directly to art music (ibid.: 9). According to this, the critically trained student will recognize the art work as being more substantial and meaningful. From today's perspective, Rauhe's approach seems undecided. On the one hand he claims that any criticism needs to be articulated by the students themselves; this may be seen as a concession to the musical reality of the young people. On the other hand, the teacher consumes a high amount of energy to make the student articulate such a criticism.

At this point it becomes evident that popular music serves as a key indicator of the transforming musical realities in the 1950s and 1960s. Various music educationalists respond to this phenomenon by postulating that music education needs to change fundamentally (Venus 1969; Abel-Struth 1970). This debate is fertilized by music educationalist Walter Gieseler with his reference to 
emancipatory ideals (Gieseler 1973). Accordingly, music education has to adopt strategies of enlightenment in order to transfer the student into the state of maturity and autonomy. Hence, music educationalists and teachers need to provide a systematic training and differentiation of the listening experience. This merges into to the concept of ästhetische erziehung in der Musik (aesthetic education in music; ibid.: 20).

The re-orientation of music education is accompanied (respectively supported) by the rise of communication and media theories (Ekman and Friesen 1969, Prokop 1972). Subsequently, musical reality is interpreted as an entity of encoding and decoding processes executed by "transmitters" and "receivers". Central to this conception is the hypothesis of the artwork containing a range of information in itself which is characterized by optimal transmission power (Thiele 1972: 79). This implies that every artwork reveals an affinity to a certain target group. Some years after his jazz didactics Rauhe (1972) adopts the concept of target group affinity, incorporating it into his notion of aesthetic education. Thus, the range of potential musical subjects is extended to visual manifestations such as films, performances, packaging, etc. But still, the programmatic core of Rauhe's conception is to be found in the Adornian agenda. Altogether, the music lesson shall promote the optimal utilization of perception and interaction strategies by producing alternative behaviours and attitudes (ibid.: 142-146). In other words music education is laid out to transform the students into the target group of complex and intellectually challenging, that is to say non-popular, artistic production.

The curricula of that time express the didactic objectives mentioned above almost in an identical form. ${ }^{5}$ Overall, school education aims to transform the young into responsible citizens. Translated into the language of the music curriculum, this means that the students shall adopt a mature attitude towards the musical output of everyday life (Der Hessische Kultusminister 1976: 7). As explained in terms of didactic theory, mass culture is given particular significance with regard to the formulation of general and subject-specific learning goals. Thereafter, it is essential to protect the student from becoming a defenceless object of any manipulation (ibid.: 5). Reversed into positive diction, this means the students have to be lead towards a critical listening attitude (Der Kultusminister des Landes Schleswig-Holstein 1991 [1976]: 365). Some curricula reveal a broad concept of music, suggesting an intensive study of akustischästhetische Phänomene ("sonic-aesthetic phenomena"; Der Hessische Kultusminister 1976: 5; see also Der Kultusminister des Landes NordrheinWestfalen 1973: 68). However, most of the curricula do not convey radical ideas; they rather balance out the progressive tendencies within the art and pop world of that time (sound installation, Fluxus, psychedelia etc.) and the traditional understanding of music (melody, harmony, rhythm, etc.) which was prolonged in the educational discourse. 


\section{Discovering rock music. Constructive-minded approaches on the rise}

It was only in the mid-1980s when critical teaching of popular music was gradually completed by affirmative didactic approaches. From then on, it took another decade until references to critical thinking would disappear almost completely from theoretical and curricular discourse. Noticeable about the initial period of constructive-minded popular music education is the preference of the term Rockmusik ("rock music"; Schütz 1982, Lugert 1984, Niermann 1987). From today's perspective this can be attributed primarily to two factors: Firstly, the pioneers of (international) popular music studies tended to refer to research topics that were related to (subversive) youth cultures, which were connoted as "rock" (Frith 1978; Willis 1978; Wicke 1986); music educationalists in turn oriented to those studies. Secondly, rock music was a dominant pop cultural practice at the time. ${ }^{6}$ Hence, a new generation of music educationalists and music teachers was socialized under the banner of "rock heroes" such as The Rolling Stones, The Who or Led Zeppelin. ${ }^{7}$

In order to illustrate the fundamental shift within music education in the 1980s, a reference shall first be made to Volker Schütz' monograph Rockmusik (Schütz 1982). The term "rock music" derives from the author's objective to focus on a specific section within the broad field of popular music (ibid.: 140). Already at this level it becomes evident what is crucial about the affirmative or constructiveminded teaching of popular music in general, namely the differentiation of stylistic diversity; by way of reminder, critical approaches only paid attention to the diverging aesthetic qualities of popular music to the extent that manipulative strategies of the culture industry could be revealed. It is crucial for Schütz' approach to invert the traditional discourse of contempt and depreciation by assuming that popular music - in this case "rock music" - is specifically suited to serve as content or method of teaching (ibid.: 167). Rock music is recommended as a methodological means to illuminate essential dimensions of musical experience, especially physio-motoric and rhythmic-periodic aspects but also the effects of consciously designed music and the emotional sensation that is connected with the individual expression through music. The teaching of rock music is intended to create new insights concerning the subject "rock music" as well as the subjectivity of the learner. Altogether, music lessons shall allow the students to understand the musical structure of rock music, its shape, its (textual) contents and its effect as well as its genesis, stylistic progress and social significance.

The question of the double-sided anchoring of subjective (that is, studentrelated) and objective (that is, music-related) requirements is also raised in Franz Niermann's rock-oriented approach (Niermann 1987). Niermann applies to the issue of subject-object-tension with the concept of interest-driven appropriation. In this sense, the mediation between student interests on the one hand and the material aspects of education theory on the other hand is set to be the crucial point of any classroom activity (ibid.: 23). According to this postulation, a new primacy of equivalence or partnership of subject and object arises, which has mainly an effect on the object. Music shall no longer be regarded as a fixed shape but rather as an open set of expressive features which comprises a multitude of 
potentials for recreation; hereby, Niermann is clearly directed against the concept of Autonomieästhetik ("aesthetic autonomy"), which is an inherent part of the Adornian agenda. One of the main tasks of the teacher is then to initiate classroom activity on the basis of the students' horizon of knowledge and experience and to broaden it successively in the course of teaching units (ibid.: 44). As in Schütz' approach the balancing out of making music and music analysis is a central demand.

During the 1990s the focus on rock music wanes; instead, popular music is increasingly addressed in its "entirety". Evidence for this can be seen in the preference of the term Pop-/Rockmusik ("pop and rock music"). Quite remarkable about nineties didactic discourse is that popular music is now taken as an indisputable cultural factor. To put it in other words: popular music no longer needs to be legitimized. Nevertheless, the common recognition and appreciation cannot hide the fact that popular music, as Ansgar Jerrentrup puts it, challenges the occidental humanistic understanding of school education (Jerrentrup 1997: 280). Concerning the material level of education, this problem may not seem too serious. Hence, the aesthetic categories can be easily shifted from the paradigm of compositional structure to rhythmic, performative or technological aspects (ibid.: 283). But the socio-psychological features of popular music outweigh the aesthetic level. Keywords such as daydreaming, exuberance, escapism or rebellion suggest that the existentialist level of popular music experience resists the traditional objectives of school education (ibid.: 284). Further problems occur due to the vast day-to-day output of new products, constantly changing style and genre patterns and gender specific preferences. Eventually, Jerrentrup claims that those musical objects which play a leading role in the current shaping of youth culture shall not be dealt with due to the emphatic resonance they produce. ${ }^{8}$

At this point, it becomes clear that an affirmative approach on popular music also needs to be attributed as being "realistic". The myriad problems that are connected with contemporary popular culture are far from being solved. In the section on what may actually be taught, Jerrentrup (1997) mentions a rather interesting point which casts a light on the teaching of popular music beyond current trends. In concrete terms, he suggests addressing original manifestations of popular music (ibid.: 298-299). This seems plausible, but implies at the same time some far-reaching consequences. It requires the teacher to be a true expert of past and present popular music. Otherwise it may occur that a phenomenon is being introduced which is not new or original to the students at all. Subsequently, the teacher's position of being an expert would suffer. The expertise of the teacher is to be discussed more in-depth in the final section of the paper.

As in the case of 1960 s and 1970s education, the curricula convey the same basic principles that are articulated in the context of theoretical reflection. ${ }^{9}$ Specifically, this means most of the curricula aim for a differentiated, now and again time-intensive treatment of popular music. This is justified by the fact that contemporary music education has to pick up the individual experiences of each student. Every learning process needs to start from the students' preferences and habits. Thus, it shall not be the aim of school education to engage in the formation of new listening habits (Der Minister für Kultus, Bildung und Wissenschaft Saarland 1988: 292), which has been explicitly postulated in the 1960s and 1970s curricula (see above). It is now the general objective to make 
the students accessible to musical worlds which transgress their hitherto favoured music (Der Hessische Kultusminister 1991 [1985]: 50). Furthermore, it is indicative for the curricular agenda that popular music is considered to be exterior to the aesthetic norms of western art music (Ministerium für Kultus und Sport Baden-Württemberg 1991 [1983]: 78). Accordingly, some curricula postulate that any judging criteria shall be deduced only in reference to the aesthetic, historic and social complex of popular music. Another aim is to enable the students to differentiate between the various styles and genres of popular music (Der Minister für Kultus, Bildung und Wissenschaft Saarland 1991 [1980]: 194); as mentioned above, this is a distinct indication of an affirmative approach towards popular music. What is new to the curricula is the fact that dealing with popular music includes the recognition and classification of typical features of Afro-American heritage (Der Minister für Kultus, Bildung und Wissenschaft Saarland 1991 [1988]: 291). This is framed by an overall appreciation of "foreign" music cultures. $^{10}$

\section{Making popular music. The primacy of action-oriented teaching}

The 1980s marked a shift away from critique-oriented school education. Along with this change the objectives of music education underwent a general revision. This means that as in the 1960s and 1970s, when almost every didactic decision was made against the backdrop of emancipatory ideals, the discourse on teaching popular music was again influenced by overall debates on how future school education should be constituted. Central to this trend was the notion of humanity and holistic experience. The critical approach was now regarded as being "too" rational and, in the end, "too" narrow. Also students were no longer seen as passive consumers but (in accordance with phenomenological epistemology) as coexisting actors who create their own realities (Meyer-Drawe 1984).

Music educationalist Bernhard Binkowski (1978) adopts the idea of humanity, postulating it as a music educational paradigm. The demand for humanising is based on the diagnosis that school education is determined by an overemphasis on the intellect. According to Binkowski, humanisation, in contrast, enhances the emotional, creative, social and physical aspects of education (ibid.: 13). However, it is not only given to music lessons to meet the needs of a humane school. Rather, all subjects must internalize the overarching goal of humanisation. The special quality of music teaching lies in its ability to contribute to the promotion of physical well-being (ibid.: 14). Likewise, music lessons can enable a farreaching emotional development of the student's personality while simultaneously promoting strategies of rational control. With regard to the future design of music education this implies that the students need to be enabled to enjoy music or even to be seized with it.

In line with humanisation theories music teaching becomes associated with the idea of creating a "school of life" in addition to the traditional "learning school". On the field of music education, this aim can be achieved by discarding the concept of a verbal-oriented subject which is more or less equal to other subjects (Ehrenforth 1978). Emotions, more precisely, the evoking of emotions would then 
have to form the centrepiece of any music lesson. It is a common view of the time, to consider musical experience as being determined by an integrated set of stimuli, events and (inter)personal characteristics. Nevertheless, the processing within musical perception becomes increasingly interpreted as being led by emotional categories such as sympathy or empathy. In line with this, the internal conditions of musical experience become a focus of educational thinking. For instance, music educationalist Rudolf Nykrin (1978: 71) suggests that music teaching primarily has to work towards a change of the student's attitude, which in detail means that he or she shall achieve a greater openness towards musical realities. Such changes are unlikely to be achieved solely by a reflexive-accented approach on musical habits. An alteration of attitude can only be achieved by the testing of new action patterns and a responsible guidance and support from the teacher. Equally important, however, is the acknowledgement the teacher expresses towards the student performances ("empathy"; ibid.).

While the discourse on humanising music education is not linked to any specific type of music, it sets a general direction, which, eventually, affects the discourse on teaching popular music. Thus, Schütz, who in the early eighties advocated a balance between practical skills and music analysis (see above), shifts towards an action-centred agenda (Schütz 1995). Henceforth, it seems desirable to teach aesthetic standards of pop and rock music on the basis of rhythmic patterns, the blues and the pentatonic scale, bodily movements, and so forth. This set of teaching components is framed by the overall didactic conception of Aufbau einer ästhetischen Handlungskompetenz ("establishing aesthetic action competence"; ibid.: 272). According to this, music is to be treated as a manifestation of the fundamental right of all people to individual and collective expression, to the testing and unfolding of aesthetic skills and potentials (ibid.). ${ }^{11}$

The change within pedagogical discourse can also be reconstructed with reference to the curricular situation. The 1980s and 1990s marked the beginning of a development in which the idea of a preferably action-based and open learning process has been increasingly conveyed. Additionally, music education is set up as "humane education". On the other hand, emancipation and maturity postulates are not explicitly mentioned, neither is the requirement of imparting a value system for critical listening. The rational-critical approach is weakened in favour of a holistic conception of the student's personality. Accordingly, the school-based influence on the everyday life is limited to the provision of a "musical orientation guide" ("attitude"). The student is to be trained in an appropriate understanding of musical diversity and its historical dimension (Der Niedersächsische Kultusminister 1991 [1986]: 185) - the term "diversity" determines almost each level of the curricular agenda. Thereby, the cognitive dimension of learning is not neglected, but, again, several hints can be found that the targeted "orientation guide" is to be built up on the basis of practical skills. With regard to popular music, this applies to the performance against a (simplified) playback track, the reproduction of a song, the production of a new song or video clip as well as the conception of dance choreography (Der Hessische Kultusminister 1997: 24; Ministerium für Kultus und Sport BadenWürttemberg 1994: 397). 
It turns out that the humane-oriented curricula emphasise the plurality of music cultures, transforming this issue into the actual educational and aesthetic ideal. This is accompanied by an accentuation of the interactive moment of music teaching, since music-related activities represent a specific form of social interaction. Due to the constant initiation of interactive situations the students practically learn how to deal with other musical habits and aesthetic selfconceptions. It is an essential part of action-oriented teaching that, in the end, the students internalise an interaction repertoire which enables them to act spontaneously and in a creative manner, which, in turn, makes them confident actors within a diverse musical reality.

\section{Analysing popular music. The missing component?}

It is becoming clear that by no later than the 1990s music has been accentuated as a special mode of social activity and aesthetic production. This led to the overall assumption that gaining a deeper understanding of music is only possible due to the experience of its sensual and interactive qualities. In line with this broad didactic orientation several approaches which promote musical classroom activity have been elaborated. This includes the so called Streicherklassen ("string classes") or Bläserklassen ("brass classes"), which are based on the idea that students of one class are regularly taught as a music ensemble; this implies a special curriculum that entails extra class time and individual instrumental training. In the last two decades, the concept of specialized "music classes" has been increasingly put into practice. Until recent times, the concept of ensemblebased music education (whether or not related to special classes) has gained many supporters, also among educationalists who promote the teaching of popular music (Rolle 2010).

The stated trend is currently present and it raises the question if the discourse on music education, again, has produced a programmatic agenda that must be considered as "too" narrow. The historical and theoretical issues of popular music seem too complex to be reduced to the process of generating musical sounds. For this reason, the following section shall outline the didactic requirements which result from the re-evaluation of popular music as cultural practice.

What seems central to the understanding of pop and rock music is the fact that it covers a wide range of artistic phenomena and social functions. In this regard, the following point shall be stressed here: the search of collectively shared emphasis - or as Bennett (2000: 39) puts it using the example of the rock ' $\mathrm{n}$ ' roll era: "The way that rock ' $n$ ' roll music crucially differed from earlier forms of popular music was in the reflexivity of the discourse that was established between rock ' $n$ ' roll and its newly emerging youth audience". Consequently, rock ' $n$ ' roll was accompanied by a manifest coupling of youthful habits and music-related actions. From this coupling, pop and rock gained its social vitality and formative power. This implies that popular music, as we know it today, is not only about distraction or aesthetic contemplation, but is a rather complex matter. The listener becomes recognizable via music; with the help of music he or she appears as a social subject. At the same time, this reveals that popular music has never been a 
pure Tonkunst ("art of sound"). In fact, it makes those who produce the sounds while being engaged in all sorts of expressive actions stand out.

If we think of popular music as an intertwining of artistic processes, strategies of representation and modes of reception and appropriation ("cultural practice") we need to take into account a converted image of the figure of the musician. For generations, a new art of self-expression has gained prevalence. In principle, this art comprises traditional western musician types such as the virtuoso or the composer. Undeniably, also, the production of popular music needs a musical idea, which in turn must reveal a tonal structure. However, in addition to this a number of creative practices arose which are not purely tonal in nature, but which are no less important with respect to the physical appearance of a musician (see also Toynbee 2000: 34-35). This can, among others, include sound manipulation due to guitar effects or synthesizers as well as playful singing, (pseudo) erotic flirtation or acrobatic dance routines. The specific features of an artist or a group of artists cannot be conceived solely with regard to compositional or instrumental/vocal skills. Rather, idiosyncrasy is constituted on the basis of how musicians perform in various media settings. The final product always tells a story of individual artistic strategies and aesthetic self-conceptions. Last but not least, all of this occurs on the backdrop of audience expectations, shared aesthetic values and societal and cultural needs.

Take the recording, for instance. What is presented as the interplay of instruments and voices is in fact the result of a complex coupling of overdubbing, cutting, sound processing and mastering (Blake 2009). The artists are "staged" on record in a purely sonic manner; certain instrumental or vocal events are accentuated or manipulated, others are hidden. Basic insights into the sound texture and the underlying aesthetic conception emerge already by means of instrumentation. Issues to be addressed are: To what extent is an artistic identity constituted by recourse to certain instruments? What instruments can be heard throughout the song or an entire album? Which voices or instruments come to the foreground due to a certain timbre and/or a specific articulatory design? Also relevant is the fact that popular music implies a wide range of typical ensemble set-ups. Well known is the rock paradigm of a (male!) four or five piece band; it represents (more or less) the idea of an authentic genesis of musical sounds (Auslander 1999: 62-73). Since the advent of electronic dance music in the late seventies, this rock paradigm has been increasingly challenged. New ways of making and presenting music emerged which deny the concept of an authentic (meaning naturalistic) music performance. Such a systematic analysis of the basic features of a recording can also be pursued with regard to pattern and groove formation, vocal styles, noise production/reduction, harmonic structures and melody shapes.

As stated above, the aesthetic emanation within popular music culture exceeds the art of sound production. The next step would be to focus on audiovisual media, especially the music video, which, over the last three decades, had a major impact on the way pop and rock music is distributed and perceived. As part of a music video production, it is possible to stress certain aspects of an artist's aesthetic self-conception that may have existed for quite a while but literally has not been made visible. In a music video bodies, places and things are captured and rematerialized with the help of the camera. The camera allows shifting the 
ratio of detail and whole in dense sequential order; thus, it opens "impossible" views of the star persona (Vernallis 2004). In addition, the (moving) image can be organized in a narrative manner; the star then merges with fictional reality. Basic questions to address to the music video would be: Are the artists shown or not? What is the basic compositional structure: performance, narration and/or illustration? In case of performances, what is the setting about? Does it confirm or transcend the idea of a "traditional" performance? Dealing with these questions leads to a deeper understanding of the various impressions which are intentionally created due to the media-based appearance of artists and their music.

Eventually, the live performance comes into play. During a concert the star is able to indicate that he or she is tangible. Also stars may highlight the exclusiveness of the event and thereby induce a sense of community (or at least the illusion of it). It is characteristic of popular music that the real time experience of popular music performance is determined by an apparatus of technological devices (Auslander 1999). This concerns the microphone, the PA, and the stage set-up with its various effects. Of interest, however, is also the question of how the performers interpret the juxtaposition with the audience; maybe rites or interaction structures of a particular scene are reflected here (Berger 1999). From the courses of action within a performance certain gestures can stand out, which leads to the question whether social mainstream knowledge or cultural knowledge of a certain genre is addressed ("exclusiveness"). Similarly, the interaction structures which take shape between the performers are of analytic importance. In an ensemble a variety of positions and constellations is possible; this is a constitutive component of the performers' impression management, since being juxtaposed to others accentuates the identity markers of the individual.

Completing these theoretical considerations, it shall be noted that only three modes of representation have been brought into focus thus far. Due to the specific limitations of a journal article media practices such as artwork, web design or social media can only be listed for the sake of completeness. Also the role of journalists as primary communicators of popular music can merely be mentioned in passing. Despite these omissions, it is worth emphasizing that all processes of producing and receiving music are somehow intertwined. It is left to the analyst to bring light into the complex interplay of musical structures, media products, star personae, audiences, music scenes and so forth. This is supported by general questions, such as what kind of impressions may be evoked by the musical object? Which strategies of (self-) presentation are utilized? Which value systems do the artefacts relate to? These are questions which (normally) popular music studies deals with. Nevertheless, they should be part of school education. Despite of the sensual richness of (popular) music, it still seems desirable to inform the young about the processes that constitute the culture they live in. Without any doubt, this is a delicate task, since students are popular music experts due to their musical socialization. But as in any specialist environment expertise already involves narrow-mindedness and ignorance.

To give an example of how the issues raised above may be integrated into the actual teaching work: for the purpose of a class project, students organize a school concert. The project begins with a brief period of reflection, in which basically one question is to be addressed: Who participates in a pop concert? The students' answers illuminate certain fields of engagement which then constitute 
the basis of forming different workgroups. This could include the following categories: band (potentially to be recruited from other classes), stage design, sound engineering/PA, visuals/audio-visual media, logistics, public relations, journalistic review, and audience (the latter group somehow ranges between fan and fieldwork perspective). ${ }^{12}$ In the further course of the project the students draw up a detailed description of what they experience while fulfilling their roles. By this means, a set of work records is being produced which serves as the key element of intermediate project evaluations which involve the whole class - in addition to this, various work materials (statistics, graphics, documentaries etc.) may be passed out. The didactic value of such an approach refers to the following aspects: The students develop a sensibility for the complexity in popular music cultures, since it is brought to light that the actual pop experience presupposes a coordinated interplay of various "experts" - what is decisive here is the double access to musical expertise: via interaction and reflection. Furthermore, popular music is revealed as an aesthetic practice which emphasizes the need to synchronise sonic, visual and corporal forms of representation by involving media technology. And, finally, it can be seen that any performance of popular music binds to a variety of aesthetic and social codes that are communicatively processed in both informal (fan-based) and professional (journalistic) circles. ${ }^{13}$

\section{Conclusion}

Within the preceding sections the "long path" from critical to post-critical teaching of popular music has been targeted. It can be shown that the Adornian agenda once marked the starting point of a sustainable confrontation of music education with the youth-related phenomenon of "popular music". Due to the reference to Adorno and the Frankfurt School agenda the teaching process was laid out to be highly analytical and at the same time pejorative. It took a new generation of music educationalists, who grew up with rock and pop music, to overcome the Adornian approach; popular music had to be re-discovered. This process was accompanied by a general revision of school education in favour of holistic approaches. In line with this, the teaching of popular music developed towards the training of practical skills, a tendency that with regard to the cultural dimension of popular music has to be scrutinized.

Alongside a variety of issues, the study of post-critical popular music education stresses one argument, namely that any didactic conception needs to differentiate between the aspects of cultural constitution and musical materialization, treating both as two sides of the same coin. Hence, it can be shown that there is not one crucial didactic problem that needs to be resolved for all time. Rather, a multiplicity of risks and problems exists which are tied to specific phenomena and which can only be addressed by the individual didactic actions of the teacher. This also implies that some musical phenomena may be more (or less) suitable for a specific grade or teaching method. The subject "popular music" prompts the teacher to adopt an extensive and differentiated horizon of knowledge which enables him or her to identify the basic features and critical points of a particular teaching material in a quick and reliable manner (in this sense, the analytic facet of the Frankfurt School agenda would be re-vitalized). Today, this occurs, most 
notably, as a practical problem, since popular music studies is not offered on a large-scale basis across German universities and teachers' training colleges.

But beyond any institutional matters: if a network of meanings and artistic processes is disclosed by the teacher prior to the actual lesson, it is of secondary importance, which method is being used. Whether then a pop song is imparted by singing or a video clip is produced in a project-based setting, the main objective should be to embed the newly acquired skills in a broader, in other words cultural understanding of music. This conception implies a sensitivity to certain issues (media production, stardom, performance etc.), respectively, to further courses of action. In other words, teaching needs to promote a "big picture" understanding of things. Behind this seemingly simple concept lies a fundamental principle of modern didactics, namely to open up the students' insights into the constitution of culture, and to show them how to take an active part in shaping culture. Students thereby acquire a key competence in times of global networking and cultural diversification, which is the ability to structure changing cultural contexts independently and to provide them with meaning.

\section{Endnotes}

${ }^{1}$ Due to its subheading Orientierung am Kunstwerk ("orientation towards the artwork") Alt's work is consistently referred to as Kunstwerkdidaktik ("artwork didactics") in the German music educational discourse.

${ }^{2}$ For further reading on Alt's reception of Adorno's works see Uhden (2013).

${ }^{3}$ About the same time, the volume Jazz in der Schule ("Jazz in School") by Schulz-Koehn and Gieseler (1959) was published. However, it did not enjoy the same appreciation as Rauhe's work, which certainly is related to the fact that throughout his career Rauhe published a series of books and articles concerning the teaching of popular music, eventually becoming one of the most prominent exponents of popular music education in Germany.

${ }^{4}$ Moreover, the contiguity to the Adornian agenda is clearly indicated due to the dialectic intertwining of product features ("disguise of the triads") and global psychological conditions ("vagueness of feelings").

${ }^{5}$ The educational system in Germany is organized in accordance to the federal political system, which has the effect that sixteen different traditions and practices (according to the sixteen federal states) shape the curricular situation. Nevertheless, due to the work of several supra-regional commissions and councils educational goals are harmonized with one another. In line with this study, fifty-five curricula in the period from 1954 to 2002 have been surveyed and evaluated. State-specific features have not been taken into account.

${ }^{6}$ From a historical distance, this circumstance surely needs to be challenged with regard to its chauvinistic potentials (see Railton 2001).

${ }^{7}$ German music educationalist Jürgen Terhag emphasizes the fundamental importance of musical socialization for the handling of popular music. Terhag (1989: 247-253) even interprets the need for an approximation to the musical experiences of the students as a question of survival for the teacher. But since musical socialization through pop and rock music is no standard, training programs at universities need to build up a horizon of experience in the field of popular music. 
${ }^{8}$ In his examination on classroom-related student behavior Terhag (1989: 48-50) comes to the same conclusion. Terhag argues in favor of the differentiation of Schüler-Musik ("students' music"), that is current music which is emphatically received by the young (and therefore not suitable for teaching), and Schul-Musik ("school music"), that is music that enjoys only little emphasis by the students. In practical terms, this implies that popular music is to some extent non-teachable.

${ }^{9}$ At the same time, they reveal a particularly dense and teleological diction by which educational priorities and tendencies take shape which cannot be fully detected in theoretical works.

${ }^{10}$ Most of the examined curricula include the objective of dealing with non-European music cultures.

${ }^{11}$ Concerning current conceptions and discussions on action-based teaching see Maas and Terhag (2010).

${ }^{12}$ Since the average class size in German schools (secondary education) amounts to twenty-five students the number of work groups seems adequate. In the case of smaller classes certain work groups may be pooled.

${ }^{13}$ The project is most likely to suit children aged fourteen to sixteen years. With older students both the level of abstraction and the complexity of practical applications may be heightened, for example, on the basis of a detailed video clip analysis, followed by a video clip production. In this case, one could make use of the participatory element of the Internet. It is now a widespread practice that artists use their online presence to call on the web communities to create video clips for their songs. The students would have to seek out such a call. As a result of this, the teaching of popular music would, in the end, transcend the institutional barriers of education and enter the world of cultural practice.

\section{References}

Abel-Struth, S. 1970. Materialien zur Entwicklung der Musikpädagogik als Wissenschaft. Mainz: Schott.

Alt, M. 1968. Didaktik der Musik. Orientierung am Kunstwerk. Düsseldorf: Pädagogischer Verlag Schwann.

Adorno, T. W. 1983. Ästhetische Theorie. 6th Edition. Frankfurt am Main: Suhrkamp. 1990. On Popular Music [1941]. In S. Frith and A. Goodwin Eds. On Record. Rock, Pop, and the Written Word. London: Routledge: 301-314.

Auslander, P. 1999. Liveness. Performance in a Mediatized Culture. London: Routledge.

Bennett, A. 2000. Popular Music and Youth Culture. Music, Identity and Place. Basingstoke: Palgrave Macmillan.

Berger, H. M. 1999. Metal, Rock, and Jazz. Perception and the Phenomenology of Musical Experience. Hanover: University Press of New England.

Blake, A. 2009. Recording Practices and the Role of the Producer. In N. Cook et al. Eds. The Cambridge Companion to Recorded Music. Cambridge: Cambridge University Press: 36-53. 
Binkowski, B. 1978. Musik in einer humanen Schule. In E. Kraus Ed. Musik in einer humanen Schule. Vorträge der zwölften Bundesschulmusikwoche Karlsruhe 1978. Mainz: Schott: 12-16.

Der Hessische Kultusminister 1976. Rahmenrichtlinien. Sekundarstufe I Musik. Wiesbaden.

1991 [1985] Rahmenrichtlinien Sekundarstufe I, Musik. Frankfurt am Main. In Nolte E. Ed. Die neuen Curricula, Lehrpläne und Richtlinien für den Musikunterricht an den allgemeinbildenden Schulen in der Bundesrepublik Deutschland und West-Berlin II./2. Mainz: Schott: 22-69. 1997. Rahmenplan Musik, Sekundarstufe I. Frankfurt am Main.

Der Kultusminister des Landes Nordrhein-Westfalen 1973. Gesamtschule Nordrhein-Westfalen. Vorläufige Richtlinien. Kunst/Musik. Düsseldorf.

Der Kultusminister des Landes Schleswig-Holstein 1991 [1976]. Orientierungsstufe Musik. In Nolte E. Ed. Die neuen Curricula, Lehrpläne und Richtlinien für den Musikunterricht an den allgemeinbildenden Schulen in der Bundesrepublik Deutschland und West-Berlin II./3. Mainz: Schott: 365.

Der Minister für Kultus, Bildung und Wissenschaft Saarland 1991 [1980]. Vorläufiger Lehrplan für die Klassenstufen 7 bis 9 - Hauptschule - Musik. Saarbrücken. In E. Nolte Ed. Die neuen Curricula, Lehrpläne und Richtlinien für den Musikunterricht an den allgemeinbildenden Schulen in der Bundesrepublik Deutschland und West-Berlin II/3. Mainz: Schott: 174200.

1991 [1988]. Lehrplan für die Klassenstufen 9/10 - Gymnasium - Musik. Saarbrücken. In Nolte E. Ed. Die neuen Curricula, Lehrpläne und Richtlinien für den Musikunterricht an den allgemeinbildenden Schulen in der Bundesrepublik Deutschland und West-Berlin II/3. Mainz: Schott: 291-309.

Der Niedersächsische Kultusminister 1991 [1986]. Rahmenrichtlinien für das Gymnasium, Musik. In Nolte E. Ed. Die neuen Curricula, Lehrpläne und Richtlinien für den Musikunterricht an den allgemeinbildenden Schulen in der Bundesrepublik Deutschland und West-Berlin II/2. Mainz: Schott: 166-202.

Ehrenforth, K. H. 1978. Emotionalität und Humanität. Grundsätzliche Anmerkungen zum besonderen Auftrag der Musikerziehung in einer humanen Schule. Musik und Bildung 10 (1): 31-36.

Ekman, P. and Friesen, W. V. 1969. The Repertoire of Nonverbal Behavior: Categories, Origins, Usage, and Coding. Semiotica 1 (1): 49-98.

Frith, S. 1978. The Sociology of Rock. London: Constable.

Gieseler, W. 1973. Grundriss der Musikdidaktik. Wuppertal: Henn.

Horkheimer, M. and Adorno, T. W. 1998. Dialektik der Aufklärung. Special Itd. edition. Frankfurt am Main: Suhrkamp.

Jerrentrup, A. 1997. Pop-/Rockmusik im Unterricht. In S. Helms, R. Schneider, and R. Weber Eds. Handbuch des Musikunterrichts. Sekundarstufe I. Kassel: Bosse: 279-304.

Kohler, G. and Müller-Doohm, S. Eds. 2008. Wozu Adorno? Beiträge zur Kritik und zum Fortbestand einer Schlüsseltheorie des 20. Jahrhunderts. Weilerswist: Velbrück Wissenschaft.

Lugert, W. D. 1984. Rockmusik in der Schule - Stand, Probleme und Perspektiven. Musik und Bildung 16 (5): 340-343. 
Maas, G. and Terhag, J. Eds. 2010. Musikunterricht heute. Zwischen Rockklassikern und Eintagsfliegen - 50 Jahre Populäre Musik in der Schule. Oldershausen: Lugert Verlag.

Meyer-Drawe, K. 1984. Leiblichkeit und Sozialität. Phänomenologische Beiträge zu einer pädagogischen Theorie der Inter-Subjektivität. München: Wilhelm Fink.

Ministerium für Kultus und Sport Baden-Württemberg 1991 [1983]. Lehrplanrevision in Baden-Württemberg. Die revidierten Lehrpläne, Hauptschule, Musik. Villingen-Schwenningen. In E. Nolte Ed. Die neuen Curricula, Lehrpläne und Richtlinien für den Musikunterricht an den allgemeinbildenden Schulen in der Bundesrepublik Deutschland und WestBerlin II/1. Mainz: Schott: 52-79.

Ministerium für Kultus und Sport Baden-Württemberg 1994. Bildungsplan für das Gymnasium. Villingen-Schwenningen.

Niermann, F. 1987. Rockmusik und Unterricht. Eigene Wege für den Alltag mit Musik. Stuttgart: Metzlersche Verlagsbuchhandlung.

Nykrin, R. 1978. Erfahrungserschließende Musikerziehung. KonzepteArgumente - Bilder. Regensburg: Bosse.

Prokop, D. -

Ed. 1972. Massenkommunikationsforschung. I. 1: Produktion. Frankfurt am Main: Fischer. 2003. Mit Adorno gegen Adorno. Negative Dialektik der Kulturindustrie. Hamburg: VSA.

Rauhe, Hermann -

1962. Musikerziehung durch Jazz. Wolfenbüttel: Möseler.

1972. Fächerübergreifende Verankerung und Erweiterung des Musikunterrichts und Perspektiven seiner Integration in den Gesamtbereich ästhetischer Erziehung. In Kraus E. Ed. Musik in Schule und Gesellschaft. Vorträge der neunten Bundesschulmusikwoche Kassel 1972. Mainz: Schott: 116-147.

Railton, D. 2001. The Gendered Carnival of Pop. Popular Music 20 (3): 321-331.

Rolle, C. 2010. Über Didaktik Populärer Musik. Gedanken zur UnUnterrichtbarkeit aus der Perspektive ästhetischer Bildung. In G. Maas and J. Terhag Eds. Musikunterricht heute. Zwischen Rockklassikern und Eintagsfliegen - 50 Jahre Populäre Musik in der Schule. Oldershausen: Lugert Verlag: 48-57.

Schütz, V. -

1982. Rockmusik. Eine Herausforderung für Schüler und Lehrer. Oldenburg: Isensee.

1995. Didaktik der Pop/Rockmusik - Begründungsaspekte. In S. Helms, R. Schneider and R. Weber Eds. Kompendium der Musikpädagogik. Kassel: Bosse: 262-280.

Schulz-Koehn, D. and Gieseler, W. 1959. Jazz in der Schule. Wolfenbüttel: Möseler.

Terhag, J. 1989. Populäre Musik und Jugendkulturen. Über die Möglichkeiten und Grenzen der Musikpädagogik. Regensburg: Bosse.

Thiele, J. 1972. Informationen über neuere Richtungen der Ästhetik. Kriterien für deren Bedeutung hinsichtlich Beschreibung und Analyse ästhetischer und pädagogischer Kommunikation. In E. Kraus Ed. Musik in Schule und 
Gesellschaft. Vorträge der neunten Bundesschulmusikwoche Kassel 1972.

Mainz: Schott: 68-79.

Toynbee, J. 2000. Making Popular Music. Musicians, Creativity and Institutions.

London: Arnold.

Uhden, P. 2013. Die Einflüsse Theodor W. Adornos in der Didaktik Michael Alts.

Schriften Online: Musikpädagogik 2. http://www.qucosa.de. Accessed 28

February 2015.

Venus, D. 1969. Unterweisung im Musikhören. Wuppertal: Henn.

Vernallis, C. 2004. Experiencing Music Video. Aesthetics and Cultural Context.

New York: Columbia University Press.

Wicke, P. 1986. Rockmusik. Zur Ästhetik und Soziologie eines Massenmediums.

Leipzig: Reclam.

Willis, P. E. 1978. Profane Culture. Routledge: London. 